\title{
Perturbed Chloride Homeostasis and GABAergic Signaling in Human Temporal Lobe Epilepsy
}

\author{
Gilles Huberfeld, ${ }^{1,2,3 *}$ Lucia Wittner, ${ }^{1,4 *}$ Stéphane Clemenceau, ${ }^{1,2}$ Michel Baulac, ${ }^{1,2}$ Kai Kaila, ${ }^{5,6}$ Richard Miles, ${ }^{1}$ and \\ Claudio Rivera ${ }^{7}$ \\ ${ }^{1}$ INSERM U739, ${ }^{2}$ Epilepsy Unit, and ${ }^{3}$ Laboratoire de Neurophysiologie, Faculté de Médecine Pitié-Salpêtrière, Université Pierre et Marie Curie Paris 6, \\ IFR70, CHU Pitié-Salpêtrière, 75013 Paris, France, ${ }^{4}$ Institute of Experimental Medicine, Hungarian Academy of Sciences, H-1083, Budapest, Hungary, and \\ ${ }^{5}$ Department of Biological and Environmental Sciences, ${ }^{6}$ Neuroscience Center, and ${ }^{7}$ Institute of Biotechnology, University of Helsinki, FI-00014, Helsinki, \\ Finland
}

Changes in chloride $\left(\mathrm{Cl}^{-}\right)$homeostasis may be involved in the generation of some epileptic activities. In this study, we asked whether $\mathrm{Cl}^{-}$ homeostasis, and thus GABAergic signaling, is altered in tissue from patients with mesial temporal lobe epilepsy associated with hippocampal sclerosis. Slices prepared from this human tissue generated a spontaneous interictal-like activity that was initiated in the subiculum. Records from a minority of subicular pyramidal cells revealed depolarizing $\mathrm{GABA}_{\mathrm{A}}$ receptor-mediated postsynaptic events, indicating a perturbed $\mathrm{Cl}^{-}$homeostasis. We assessed possible contributions of changes in expression of the potassium-chloride cotransporter KCC2. Double in situ hybridization showed that mRNA for KCC2 was absent from 30\% of CaMKII $\alpha$ (calcium/calmodulindependent protein kinase II $\alpha$ )-positive subicular pyramidal cells. Combining intracellular recordings with biocytin-filled electrodes and KCC2 immunochemistry, we observed that all cells that were hyperpolarized during interictal events were immunopositive for KCC2, whereas the majority of depolarized cells were immunonegative. Bumetanide, at doses that selectively block the chloride-importing potassium-sodium-chloride cotransporter NKCC1, produced a hyperpolarizing shift in $\mathrm{GABA}_{\mathrm{A}}$ reversal potentials and suppressed interictal activity. Changes in $\mathrm{Cl}^{-}$transporter expression thus contribute to human epileptiform activity, and molecules acting on these transporters may be useful antiepileptic drugs.

Key words: GABA; KCC2; NKCC1; epilepsy; subiculum; bumetanide

\section{Introduction}

The epilepsies have often been linked to deficits in GABAergic signaling. Synaptic currents induced when GABA binds to $\mathrm{GABA}_{\mathrm{A}}$ receptors are carried by chloride $\left(\mathrm{Cl}^{-}\right)$and, to a lesser degree, by bicarbonate $\left(\mathrm{HCO}_{3}^{-}\right)$. $\mathrm{GABA}_{\mathrm{A}}$ receptor-mediated conductances either hyperpolarize or depolarize a neuron depending on its internal $\mathrm{Cl}^{-}$and $\mathrm{HCO}_{3}^{-}$concentrations and membrane potential. Pathological changes in $\mathrm{Cl}^{-}$homeostasis can switch GABAergic signaling from hyperpolarizing to depolarizing in epileptic tissue (Cohen et al., 2002; Haug et al., 2003; Khalilov et al., 2003), but the basis of this change is unclear. Two cation-chloride cotransporters may be especially important in controlling neuro-

\footnotetext{
Received Jan. 8, 2007; accepted July 22, 2007.

This work was supported by INSERM, the Academy of Finland, the Biocentrum Helsinki, and by grants from the European Community (EC) (EPICURE-LSH-CT-2006-037315), the Agence Nationale de Recherches, the EC, and the S. Juselius Foundation. G.H. was supported by fellowships from Assistance Publique-Hôpitaux de Paris and Centre National de la Recherche Scientifique. L.W. was supported by fellowships from INSERM and NATO. K.K. is a member of the Nordic Center of Excellence, WIRED. We thank Emmanuel Eugene for help with the imaging, Caroline LeDuigou for help with recordings, Marion Noulhiane for help with the statistics, and M. Heikura and M. Palviainen for excellent technical support. We thank Zsofi Maglóczky and Istvan Ulbert for the gift of fixed monkey hippocampal tissue.

${ }^{*} G$.H. and L.W. contributed equally to this work.

Correspondence should be addressed to Dr. Gilles Huberfeld, INSERM U739, Université Pierre et Marie Curie Paris 6, CHU Pitié-Salpêtrière, 105 Bd de l'Hôpital, 75013 Paris, France. E-mail: gilles.huberfeld@chups.jussieu.fr. DOI:10.1523/JNEUROSCI.2761-07.2007

Copyright $\odot 2007$ Society for Neuroscience $\quad$ 0270-6474/07/279866-08\$15.00/0
}

nal $\mathrm{Cl}^{-}$(Payne et al., 2003; Sipila et al., 2006): the Na-K-2Cl cotransporter NKCC1 loads neurons with $\mathrm{Cl}^{-}$and favors depolarizing responses to $\mathrm{GABA}$, whereas the $\mathrm{K}-\mathrm{Cl}$ cotransporter KCC2 normally extrudes $\mathrm{Cl}^{-}$, promoting hyperpolarizing responses.

Expression and function of both transporters are controlled at multiple levels. During development, KCC2 expression is upregulated and NKCC1 is downregulated (Plotkin et al., 1997; Rivera et al., 1999; Dzhala et al., 2005; Vanhatalo et al., 2005). These changes coincide with a hyperpolarizing shift in the reversal potential of cortical pyramidal cell GABAergic responses (Ben-Ari et al., 1989; Payne et al., 2003; Farrant and Kaila, 2007). In the adult, deafferentation and trauma downregulate KCC2, decrease $\mathrm{Cl}^{-}$extrusion, and induce a depolarizing shift in $\mathrm{GABA}_{\mathrm{A}}$ receptor-mediated responses (Katchman et al., 1994; van den Pol et al., 1996; Vale and Sanes, 2000; Nabekura et al., 2002; Rivera et al., 2002; Coull et al., 2003; Topolnik et al., 2003). Furthermore, both KCC2 and NKCC1 are highly regulated by phosphorylation and other post-transcriptional mechanisms (Russell, 2000; Balakrishnan et al., 2003; Vale et al., 2003; Khirug et al., 2005; Blaesse et al., 2006; de Los Heros et al., 2006).

Depolarizing GABAergic responses derived from changes in cotransporter function resulting in an elevated internal $\mathrm{Cl}^{-}$have been associated with epileptiform activity (Payne et al., 2003). Paroxysmal activity downregulates KCC2 (Rivera et al., 2004), 
and depolarizing GABAergic events are involved in the emergence of mirror epileptic foci (Khalilov et al., 2003). In patients with temporal lobe epilepsies, depolarizing GABAergic events in a minority of subicular pyramidal cells (Cohen et al., 2002) contribute to interictal-like activity generated in the subiculum. A perturbed $\mathrm{Cl}^{-}$homeostasis could explain why pro-GABAergic drugs are generally ineffective in controlling temporal lobe seizures (Semah et al., 1998).

We therefore examined GABAergic signaling and KCC2 expression in subicular pyramidal cells of patients with temporal lobe epilepsy and hippocampal sclerosis. $\mathrm{GABA}_{\mathrm{A}}$-mediated IPSPs reversed at depolarizing potentials in $\sim 20 \%$ of pyramidal cells. These cells did not differ electrically or anatomically from cells in which GABAergic inhibition was hyperpolarizing. In situ hybridization and immunocytochemistry showed that KCC2 mRNA and protein expression was absent from a minority of subicular pyramidal cells. Combining biocytin staining and immunostaining revealed KCC2 expression was perturbed in most cells that discharged during interictal events. We found that the diuretic bumetanide, which suppresses NKCC1-mediated $\mathrm{Cl}^{-}$accumulation, restored hyperpolarizing GABAergic signaling and blocked epileptiform activity.

\section{Materials and Methods}

Patients. Temporal lobe tissue was obtained from operations on patients (age range, 20-56 years; seizures for 5-39 years) with epilepsies of the temporal lobe and hippocampal sclerosis. All patients gave a written consent, and our protocol was approved by the Comité Consultatif National d'Ethique.

Tissue preparation. Tissue was transported in a cold, oxygenated solution containing (in mM) $248 \mathrm{D}$-sucrose, $26 \mathrm{NaHCO}_{3}, 1 \mathrm{KCl}, 1 \mathrm{CaCl}_{2}, 10$ $\mathrm{MgCl}_{2}$, and 10 D-glucose, equilibrated with $5 \% \mathrm{CO}_{2}$ in $95 \% \mathrm{O}_{2}$. Hippocampal-subicular slices of $400 \mu \mathrm{m}$ thickness (see Fig. $3 A$ ) were cut with a vibratome. They were maintained at $35-37^{\circ} \mathrm{C}$, equilibrated with $5 \% \mathrm{CO}_{2}$ in $95 \% \mathrm{O}_{2}$, in an interface chamber perfused with a solution containing (in mM) $124 \mathrm{NaCl}, 26 \mathrm{NaHCO}_{3}, 4 \mathrm{KCl}, 2 \mathrm{MgCl}_{2}, 2 \mathrm{CaCl}_{2}$, and 10 D-glucose. 2,3-Dioxo-6-nitro-1,2,3,4-tetrahydrobenzo

quinoxaline-7-sulfonoamide (NBQX; $10 \mu \mathrm{M})$ and D,L-APV $(100 \mu \mathrm{M})$ were used to block EPSPs.

Recordings. Intracellular records were usually made with microelectrodes that contained $2 \mathrm{M}$ KAc bevelled to a resistance of 50-90 M $\Omega$. In some experiments to measure the intracellular correlates of population field potentials, the electrodes were filled with $50 \mathrm{~mm} \mathrm{~N}$-(2,6dimethylphenylcarbamoylmethyl)-triethylammonium bromide (QX314) and $2 \mathrm{M}$ CsAc to block spiking and to achieve an improved space clamp. The data were obtained within 10-20 min of penetration, which was found to permit depolarization to potentials in the range of -30 to 0 $\mathrm{mV}$. Presumably, intracellular $\mathrm{Cs}^{+}$concentrations sufficed to block potassium and $I_{\mathrm{h}}$ channels but were not high enough to inhibit KCC2 (Williams and Payne, 2004), because hyperpolarizing $\mathrm{GABA}_{\mathrm{A}}$ reversal potentials were recorded under these conditions (see Results).

KAc in intracellular electrodes can affect measurements of responses mediated by GABA. In records from pyramidal cells in rat hippocampal slices, we found that reversal potentials of inhibitory synaptic events isolated in the presence of NBQX and D,L-APV and recorded with KAccontaining electrodes $(n=4)$ were $\sim 4 \mathrm{mV}$ more positive than those obtained when electrodes contained K methylsulfate $(n=4)$. This potential bias associated with KAc-filled electrodes seems unlikely to have affected the comparison of reversal potentials across a population of subiculum cells in epileptic tissue.

Signals were amplified with an Axoclamp 2B amplifier operated in current-clamp mode. In acceptable records, membrane potential was more negative than $-50 \mathrm{mV}$, input resistance higher than $20 \mathrm{M} \Omega$, and action potentials were overshooting. Extracellular records were made with tungsten electrodes of $\sim 10 \mu \mathrm{m}$ tip diameter (Cohen and Miles, 2000), using a differential amplifier (1700; AM Systems, Everett, WA). They were digitized with a 12-bit, 16-channel analog-to-digital converter
(Digidata 1200A; Molecular Devices, Union City, CA) and saved on a personal computer.

Double in situ hybridization. Slices were fixed in 4\% paraformaldehyde, paraffinated, and cut at $7 \mu \mathrm{m}$. The protocol for in situ hybridization was modified from Miller et al. (1993). Sections were deparaffinated, rehydrated, incubated with proteinase $\mathrm{K}(7 \mu \mathrm{g} / \mathrm{ml}$ in $50 \mathrm{~mm}$ Tris- $\mathrm{HCl}$ and $5 \mathrm{~mm}$ EDTA, pH 8.0), washed in PBS, and acetylated (1.5 mM triethanolamine- $\mathrm{HCl}, 29.3 \mathrm{~mm} \mathrm{HCl}$, and $24 \mathrm{~mm}$ acetic anhydride) for 10 min. For hybridization, both digoxigenin (Dig)-labeled and $\mathrm{S}^{35}$-labeled probes were dissolved in a solution containing $60 \%$ formamide, $0.3 \mathrm{M}$ $\mathrm{NaCl}, 20$ mм Tris- $\mathrm{HCl}$, pH 8.0, 10\% dextran sulfate, Denhart's solution (0.02\% Ficoll, $0.02 \%$ polyvinylpyrrolidone, and $0.02 \%$ bovine serum albumin), $0.5 \mathrm{mg} / \mathrm{ml}$ yeast tRNA, and $100 \mathrm{~mm}$ ditriothreitol. Posthybridization washes were followed by incubation with alkaline phosphataselabeled anti-Dig antibody (1:500) in blocking solution [0.1 M maleic acid, $0.15 \mathrm{M} \mathrm{NaCl}, 2 \%$ Boehringer Mannheim (Mannheim, Germany) blocking reagent, $10 \%$ sheep serum, $0.1 \%$ Tween 20 , and $2 \mathrm{~mm}$ levamisole]. Sections were washed, developed with BM purple (2 mM levamisole), and dehydrated. They were exposed to Biomax MR film at $-70^{\circ} \mathrm{C}$ for 1 week and dipped into NTB2 nuclear emulsion (Kodak, Rochester, NY).

Oligodeoxyribonucleotide probes were complementary to human calcium/calmodulin-dependent protein kinase II (CaMKII; BC040457, 3899-4807 bp) and human KCC2 (NM_020708, 4605-5566 bp). Fragments were cloned into pBluescript SK or a pGEM-T vector (Promega, Madison, WI). Clones were linearized by restriction digest and used as templates to generate sense and antisense $S^{35}$-labeled or Dig-labeled riboprobes. The volume densities of single- and double-labeled cells were measured following the optical fractionator probe method (West et al., 1991) using the Stereo Investigator software (MicroBrightField, Williston, VT). At least three sections per hippocampal slice per case were used. Calculations were made from photomicrographs from the different regions randomly selected by the Stereo Investigator software and of origin unknown to the investigator.

Morphology. Biocytin was injected from electrodes containing 1.6\% in $2 \mathrm{~m} \mathrm{KAc}(1.5 \mathrm{nA}$ depolarizations of $200 \mathrm{~ms}$ duration repeated at $1-3 \mathrm{~Hz}$ for at least $20 \mathrm{~min}$ ). After $1 \mathrm{~h}$, slices were fixed in $4 \%$ paraformaldehyde with $15 \%$ picric acid in $0.1 \mathrm{M} \mathrm{PBS}$ at $4^{\circ} \mathrm{C}$. They were resectioned at $70 \mu \mathrm{m}$ and freeze-thawed above liquid $\mathrm{N}_{2}$ in phosphate buffer (PB) containing $30 \%$ sucrose. Neurons were visualized by avidin-Texas Red ( 3 h, 1:500; Vector Laboratories, Burlingame, CA) with avidin-biotinylated horseradish peroxidase (ABC; 1:800; Vector Laboratories). Then, an additional immunostaining was performed (see below) on the sections containing filled cells. Cells containing biocytin were revealed with the ABC reaction $(1.5 \mathrm{~h}, 1: 250)$ using diaminobenzidine (DAB) (Sigma, St. Louis, $\mathrm{MO})$ as the chromogen. Sections were osmicated $\left(20 \mathrm{~min}, 4 \% \mathrm{OsO}_{4}\right)$, dehydrated, and mounted in Durcupan (ACM; Fluka, Buchs, Switzerland). Morphology was analyzed without knowledge of electrophysiological results from labeled cells.

Immunohistochemistry. Sixty-micrometer-thick sections were cut from fixed tissue (see above), washed with $\mathrm{PB}$, and freezed-thawed over liquid $\mathrm{N}_{2}$ in $\mathrm{PB}$ containing $30 \%$ sucrose. Endogenous peroxidase activity was blocked with $1 \% \mathrm{H}_{2} \mathrm{O}_{2}$. Nonspecific staining was suppressed with milk powder and $2 \%$ BSA containing $0.1 \%$ Triton X-100. KCC2 immunostaining used a polyclonal rabbit antibody (Payne et al., 1996) (24 h, 1:2000 dilution, $4^{\circ} \mathrm{C}$ ). In some experiments, it was revealed with the immunoperoxidase DAB method. After the KCC2 antibody, a biotinylated anti-rabbit secondary antibody was applied (2 h, 1:250; Vector Laboratories), followed by the $\mathrm{ABC}$ reaction for $1.5 \mathrm{~h}(1: 250)$ and $\mathrm{DAB}$ as the chromogen. Sections were osmicated, dehydrated, and mounted in Durcupan. In other experiments to reveal KCC2 immunostaining of biocytin-filled cells, an Alexa488-bound mouse anti-rabbit fluorescent secondary antibody (3 h, 1:250; Invitrogen, San Diego, CA) was used. Images of fluorescent immunostaining were made with a confocal microscope (SP2; Leica, Nussloch, Germany). The specificity of immmunostaining was verified according to the following criteria: (1) incubating sections without primary antibody gave no specific staining; (2) somatic or perisomatic dendritic membrane was clearly stained; and (3) membrane staining could be distinguished from nonspecific lipofuscin autofluorescence. 
A

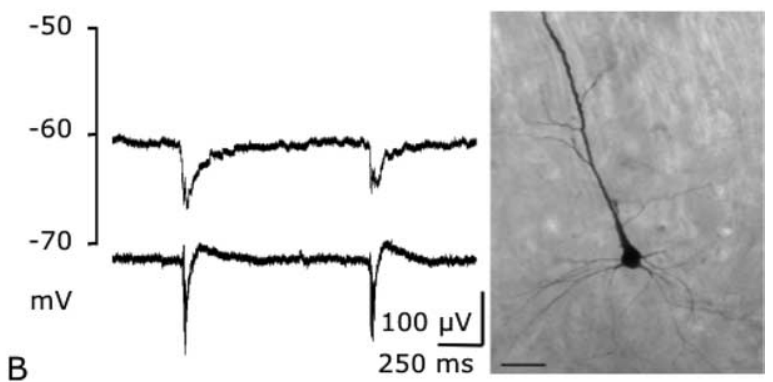

B

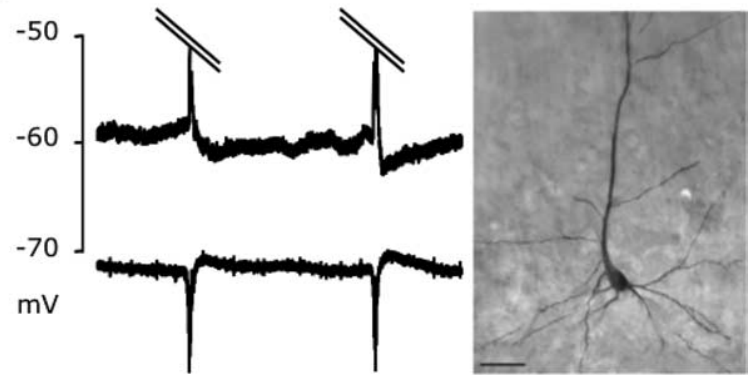

Figure 1. Two distinct pyramidal cell behaviors during interictal events. A, A subicular pyramidal cell hyperpolarized (top trace) during an extracellular epileptiform burst (bottom trace). B, A pyramidal cell (top) depolarized and discharged during epileptiform events (bottom). Action potentials are cut. Photomicrographs of each biocytin-filled cell are shown on the right. Scale bars, $25 \mu \mathrm{m}$.

Cell count. KCC2-positive and -negative principal cells in the dentate and subiculum were counted from KCC2-immunostained sections (DAB). Only surface cells with a cut, visible nucleus were counted.

Monkey tissue. Monkey hippocampal tissue from two adult animals (Macaca mulata) that were perfused for other studies was received as a gift from Istvan Ulbert (Institute for Psychology, Hungarian Academy of Sciences, Budapest, Hungary) and Zsofi Maglóczky. (Institute of Experimental Medicine, Hungarian Academy of Sciences, Budapest, Hungary). All procedures followed the National Institutes of Health Guide for the Care and Use of Laboratory Animals and were approved in advance by the Institutional Animal Care and Use Committee. Animals were deeply anesthetized by a lethal dose of pentobarbital and, immediately after cardiac arrest, were perfused through the heart with cold $\left(4^{\circ} \mathrm{C}\right)$ saline, followed by cold $4 \%$ paraformaldehyde dissolved in $0.1 \mathrm{M} \mathrm{PB}, \mathrm{pH} 7.4$. After perfusion, the brains were removed and hippocampal blocks were cut out and sectioned. Sixty-micrometer-thick sections were treated identically to human tissue.

Statistical analysis. Data are given as mean \pm SD. We used the $\chi^{2}$ test, Student's $t$ test, and an ANOVA as appropriate with a significance level of $p<0.05$.

\section{Results}

\section{Cellular behavior during interictal-like activity}

In an external solution containing $4 \mathrm{~mm}$ potassium, spontaneous interictal-like activity was generated in the subiculum of slices from epileptic patients ( 112 of 145 slices from 24 of 27 patients). It consisted of bursts of firing of 20-50 ms duration associated with field potentials of amplitudes of $20-200 \mu \mathrm{V}$. Interictal-like bursts recurring at intervals of $0.5-5 \mathrm{~s}$ were recorded from a region of $3-5 \mathrm{~mm}^{2}$. Little multiunit activity and no population synchrony were recorded from the dentate gyrus, the CA1 area, or the entorhinal cortex.

Intracellular recordings $(n=102)$ showed that $\sim 20 \%$ of subiculum cells were depolarized and sometimes fired, whereas the remainder of cells were inhibited during epileptiform events. We compared the electrical properties of a similar number of neurons that were depolarized ( $n=35$ cells) (Fig. $1 B$ ) or hyperpo-
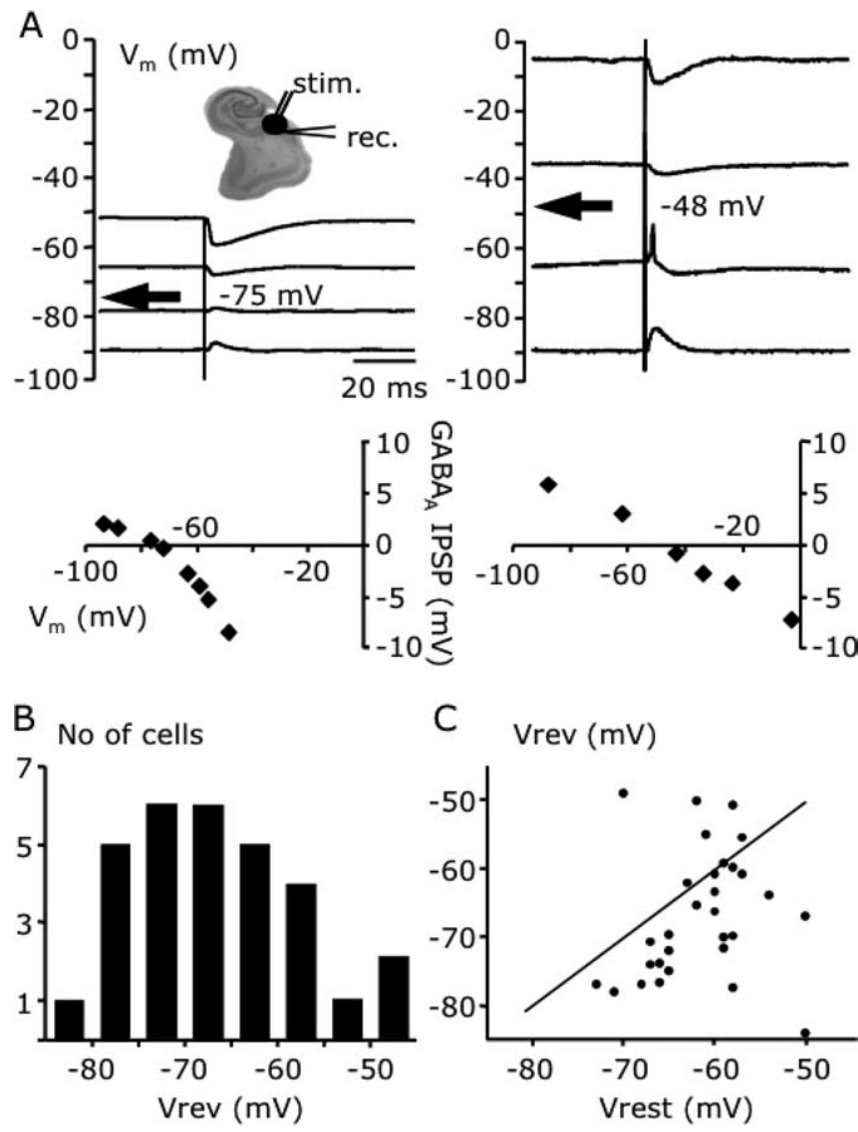

Figure 2. IPSP reversal potential $\left(V_{\text {rev }}\right)$ for cells of the epileptogenic area. $V_{\text {rev }}$ was estimated from plots of the amplitude of synaptic events, evoked by focal stimulation in $10 \mu \mathrm{m}$ NBQX and $50 \mu \mathrm{M} \mathrm{D}, \mathrm{L}-A P V$, against membrane potential. $A$, Pyramidal cells with values for $V_{\text {rev }}$ of $-75 \mathrm{mV}$ (left) and $-48 \mathrm{mV}$ (right). Top, Synaptic events at different potentials $\left(V_{\mathrm{m}}\right)$. Bottom, IPSP amplitude plotted against membrane potential. stim., Stimulation; rec., recording. $\boldsymbol{B}$, Distribution of $V_{\text {rev }}$ for 30 subicular pyramidal cells. $\boldsymbol{C}$, Correlation of $V_{\text {rev }}$ and resting potential $\left(V_{\text {rest }}\right)$ for 30 cells. Reversal potentials were depolarizing with respect to rest in six cells, above the diagonal line, and hyperpolarizing in 24 cells below the line.

larized ( $n=37$ ) (Fig. $1 A$ ) during interictal-like events. The resting potential of cells that received depolarizing synaptic events was $-61.4 \pm 4.2 \mathrm{mV}$, and their mean input resistance was $22.9 \pm$ 7.2 $\mathrm{M} \Omega$ (mean $\pm \mathrm{SD} ; n=35$ ). The resting potential of hyperpolarized cells was $-59.1 \pm 7.8 \mathrm{mV}$, and input resistance was $24.3 \pm$ $11.7 \mathrm{M} \Omega$ (mean $\pm \mathrm{SD} ; n=37)$. Neither membrane potential nor input resistance was related to the polarity of cellular responses during interictal bursts (ANOVA; membrane potential; $F_{(4,90)}=$ $1.93, p=0.11$; input resistance: $\left.F_{(4,97)}=0.95, p=0.43\right)$. Furthermore, membrane potential was not correlated with the reversal potential of GABAergic synaptic responses in 30 cells tested (bivariate fit; correlation, $0.18 ; p=0.35$ ). The intracellular correlates of population field potentials reversed at -54 and $-48 \mathrm{mV}$ for two cells that discharged with field potential and at potentials between -73 and $-61 \mathrm{mV}$ for four cells that did not fire during interictal-like events (records with electrodes containing $50 \mathrm{~mm}$ QX-314 and 2 M CsAc; data not shown).

Neurons of human epileptic subiculum, as in the rodent (Stewart and Wong, 1993), either fire in bursts or discharge repetitively. The proportions of these cell subtypes that were depolarized (17 burst firing vs 16 regular firing neurons) or hyperpolarized (14 vs 20 ) during interictal activity were not significantly different $\left(\chi^{2}\right.$ test, $\left.p=0.40\right)$.

We next asked whether neuronal behavior during interictal 

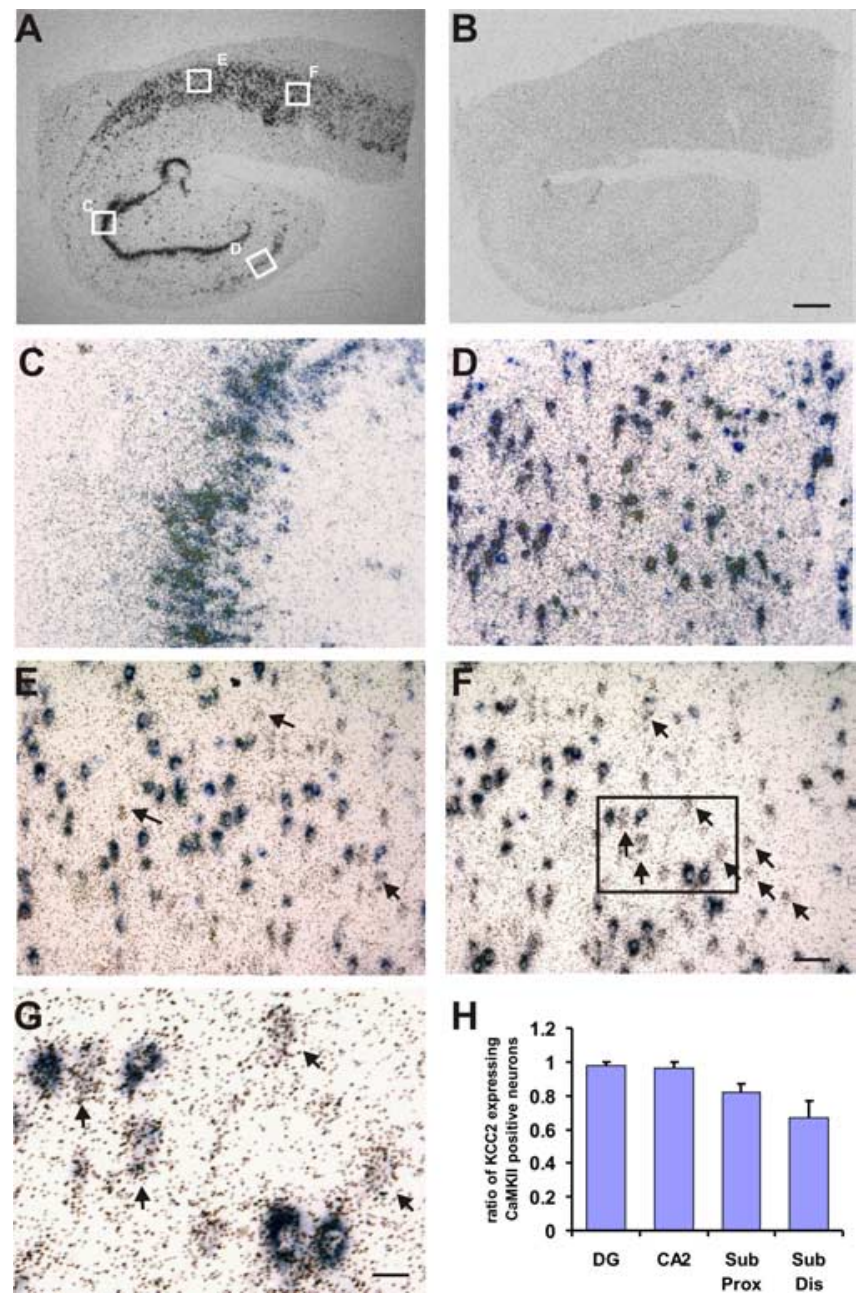

Figure 3. KCC2 mRNA is absent from a minority of subicular neurons. $\boldsymbol{A}, \mathrm{KCC} 2 \mathrm{mRNA}$ expression detected by in situ hybridization in a section from human temporal lobe. $\boldsymbol{B}$, Hybridization with sense mRNA revealed no nonspecific signal. $\mathbf{C}-\boldsymbol{F}$, Double in situ hybridization for KCC2 mRNA (BM purple) and CaMKII $\alpha\left(S^{35}\right)$ in dentate gyrus $(\boldsymbol{C}), C A 2(\boldsymbol{D})$, subiculum proximal to $C A 1$ $(\boldsymbol{D})$, and distal subiculum $(\boldsymbol{E}, \boldsymbol{F})$. Sections correspond to the labeled squares in $\boldsymbol{A}$. Arrows indicate CaMKII-positive cells with very low KCC2 mRNA levels. $G$, Higher magnification of the area inside the black square in $\boldsymbol{F}$. $\boldsymbol{H}$, Percentage of CaMKII $\alpha$ mRNA-positive cells that express KCC 2 mRNA in dentate gyrus (DG), CA2, and proximal (Prox) and distal (Dis) zones of the subiculum (Sub) plotted from Table 1. Error bars indicate SDs. Scale bars: $\boldsymbol{A}, \boldsymbol{B}, 3 \mathrm{~mm} ; \boldsymbol{C}-\boldsymbol{F}, 50 \mu \mathrm{m} ; \boldsymbol{G}, 15 \mu \mathrm{m}$.

events was correlated with cell morphology, comparing the anatomy of biocytin-filled cells from the two groups (Fig. 1). Reliably filled cells $(n=23)$ all possessed a pyramidal-shaped soma, a thick apical dendrite, and thinner basal dendrites ramifying toward the alveus. Twelve cells were depolarized during interictal events, and 11 pyramidal cells were inhibited. Pyramidal cell location within the subiculum was not related to their depolarizing or hyperpolarizing activity during population bursts. Deeper pyramidal cells of the internal pyramidal layer $(n=14)$ had long apical dendrites spanning all layers, whereas more superficial cells of the external pyramidal layer $(n=9)$ had shorter apical dendrites (Amaral and Insausti, 1990; Menendez de la Prida et al., 2003). The cells that were hyperpolarized during interictal-like events included five neurons in the internal pyramidal layer, six neurons in the external pyramidal layer, and two cells with apical dendrites that ramified near the soma. Cells discharging during population bursts included nine neurons in the internal pyramidal layer, three neurons in the external pyramidal layer, and one cell with an apical dendrite that divided near the soma. Dendritic arbors of cells that discharged and those that were inhibited were similar.

\section{Chloride homeostasis is impaired in some subicular pyramidal cells}

We next examined GABAergic signaling to confirm that it depolarizes some subicular pyramidal cells and to ask whether these cells form a separate population from those where GABA induces hyperpolarizing responses.

Subicular pyramidal cells were recorded from regions where an interictal-like activity was detected extracellularly. GABAergic synaptic events were evoked by focal electrical stimulation in the presence of NBQX $(10 \mu \mathrm{M})$ and D,L-APV $(50 \mu \mathrm{M})$. The reversal potential of synaptic events, measured from responses at different potentials (Fig. $2 A, B)$ varied between -49 and $-83 \mathrm{mV}(n=$ 30 cells). The distribution was skewed with a tail of depolarized values, a mode near $-70 \mathrm{mV}$, and no clear division into two cell groups. Subgroups could be separated according to driving force (Fig. 2C). In 24 of 30 cells (80\%), synaptic events reversed negative to resting potential: mean resting potential was $-61.5 \pm 5.9$ $\mathrm{mV}$, and reversal potential was $-70.2 \pm 6.7 \mathrm{mV}$ (mean $\pm \mathrm{SD}$; $n=24)$. In six cells, synaptic events reversed depolarized to rest: mean resting potential was $-61.8 \pm 4.6 \mathrm{mV}$, and reversal potential was $-53.7 \pm 4.9 \mathrm{mV}$ (mean $\pm \mathrm{SD} ; n=6)$. There was no difference in the mean resting potential of these groups ( $t$ test; $t=$ $-0.11 ; p=0.91)$. As expected, the mean IPSP reversal potential in depolarized cells was more positive than in hyperpolarized cells ( $t$ test; $t=5.61 ; p=0.00001)$. Thus, although GABAergic signaling is perturbed, pyramidal cells do not clearly fall into two separate groups.

\section{KCC2 mRNA expression in epileptogenic human tissue}

Reduced expression of the K-Cl cotransporter KCC2 might explain a depolarizing shift in IPSP reversal potential. We therefore developed a double in situ hybridization protocol to examine KCC2 mRNA in principal cells, detected according to their expression of CaMKII $\alpha$ (Sik et al., 1998). Because KCC2 has been shown to be strongly expressed in pyramidal cell dendrites (Gulyas et al., 2001), we reasoned that somatic mRNA labeling with in situ methods might facilitate KCC2 detection.

KCC2 mRNA was detected by Dig/BM purple labeling in cells of the dentate granule, the sclerosis-resistant $\mathrm{CA} 2$ region, and the subiculum (Fig. $3 A$ ). CaMKII $\alpha$ mRNA expression, detected by $\mathrm{S}^{35}$ radioactive labeling, was used to identify principal cells (Sik et al., 1998). We evaluated the proportion of cells expressing both mRNAs in distinct areas of slices from 13 epileptic patients (Fig. $3 C-G)$. Analysis of the density of single- and double-labeled cells in the different hippocampal regions is shown in Table 1. Almost all granule cells $(98 \pm 2 \%)$ and nearly all (96 $\pm 4 \%$ ) CA2 pyramidal cells expressed KCC2 mRNA. The proportion of KCC2-negative neurons in the subiculum was higher than in the dentate and CA2 and tended to increase with distance from the border with CA1. KCC2 mRNA was detected in $82 \pm 5 \%$ of subiculum cells proximal to $\mathrm{CA} 1$ and $67 \pm 10 \%$ of distal subiculum cells (Fig. $3 H$ ). In distal regions, KCC2-negative/CaMKII $\alpha$-positive neurons were sometimes arranged in clusters of three to four cells.

KCC2 protein immunodetection in subicular pyramidal cells We next examined expression of KCC2 protein in human epileptogenic subiculum using a specific antibody and DAB as the chromogen (Fig. 4). Discrete immunostaining for KCC2 was detected on the perisomatic and dendritic membrane of most pyramidal cells (Fig. 4A). Presumed interneurons, with a nonpyramidal 
Table 1. The density of cells expressing CaMKII $\alpha$ mRNA and expressing both CaMKII $\alpha$ and KCC2 mRNAs in different hippocampal regions

\begin{tabular}{|c|c|c|c|c|c|c|}
\hline & CaMKII $\alpha$ (cells $\left./ \mathrm{mm}^{3} \times 10^{4}\right)$ & SEM & $\mathrm{KCC} 2+$ CaMKII $\alpha\left(\right.$ cells $\left./ \mathrm{mm}^{3} \times 10^{4}\right)$ & SEM & Mean ratio/slice & SEM \\
\hline$D G$ & 22.3 & 2.52 & 21.8 & 1.91 & 0.98 & 0.02 \\
\hline$C A 2$ & 1.26 & 0.16 & 1.21 & 0.19 & 0.96 & 0.04 \\
\hline Sub Prox & 1.53 & 0.17 & 1.25 & 0.20 & 0.82 & 0.05 \\
\hline Sub Dis & 1.44 & 0.23 & 0.96 & 0.26 & 0.67 & 0.1 \\
\hline
\end{tabular}

DG, Dentate gyrus; Sub Prox, proximal subiculum; Sub Dis, distal subiculum.

morphology, also showed strong KCC2 staining (Fig. 4C). We compared pyramidal cells in both proximal and distal zones of the subiculum (1673 cells in specimens from six patients) with dentate granule cells ( $n=856$ from six patients). The proportion of pyramidal cells that were immunonegative for KCC2 (Fig. 4D) was $10.6 \pm 1.9 \%$ (mean $\pm \mathrm{SD}$ ) in proximal subiculum near the CA1 region, $9.5 \pm$ $1.4 \%$ in distal subiculum closer to the presubiculum, and $3.2 \pm 3.3 \%$ in the dentate gyrus. As a control, we examined KCC2 expression in subicular pyramidal cells of tissue obtained from two healthy monkeys perfused in the course of other studies (data not shown). All 266 cells examined in the distal subiculum and 305 of 306 cells analyzed in the proximal subiculum were KCC2 immunopositive. These data suggest that KCC2 is nearly universally expressed by subicular pyramidal cells in the healthy adult primate.

\section{Correlation between single pyramidal cell behavior during interictal-like activity and KCC2 expression}

Our data show that $\mathrm{Cl}^{-}$homeostasis, determined from the reversal of GABA-mediated synaptic events, is perturbed in a minority of subicular pyramidal cells (Fig. 2) and that expression of KCC2 mRNA (Fig. 3) and protein (Fig. 4) is reduced in the subiculum. We next attempted to compare the state of $\mathrm{Cl}^{-}$homeostasis and KCC2 expression in a single cell. Recorded pyramidal cells with known behavior during interictal activity were identified by biocytin labeling, and KCC2 was detected by immunostaining (Fig. $5)$.

Pyramidal cell behavior during interictal events was classed as depolarizing or hyperpolarizing. KCC2 expression of biocytinfilled cells was assessed by merging biocytin and KCC2 labeling in confocal images. Satisfactory double labeling was observed for six pyramidal cells that were hyperpolarized during interictal-like events. All six cells expressed KCC2 (Fig. $5 A$ ) on both perisomatic and dendritic membrane. Satisfactory biocytin filling and KCC2 immunolabeling was also achieved for seven pyramidal cells that depolarized during population bursts. Three of seven biocytinfilled cells expressed KCC2. Neither diffuse nor discrete KCC2 expression was detected in four biocytin-filled cells that depolarized during epileptiform bursts (Fig. 5B).

\section{Bumetanide, an Na-K-2Cl antagonist, suppresses interictal-like activity}

A reduced KCC2 expression together with $\mathrm{Cl}^{-}$accumulation mediated by the cotransporter NKCC1 might produce depolarizing responses to GABA. We therefore asked whether the loop diuretic bumetanide, at doses that block specifically the Na-K2Cl transporter (Payne, 1997), affects epileptiform activity in adult subiculum. We first examined its effects on IPSPs induced by focal stimulation in the presence of NBQX $(10 \mu \mathrm{M})$ and D,LAPV $(50 \mu \mathrm{M})$. In four cells, bumetanide $(5-10 \mu \mathrm{M})$ induced a negative shift in the IPSP reversal potential from $-68.9 \pm 10.8$ to $-78.7 \pm 10.8 \mathrm{mV}$ (Fig. 6A).

We next examined the effects of bumetanide $(5-10 \mu \mathrm{M})$ on spontaneous epileptiform activity. In all 10 slices tested, interictal-like activity was suppressed over a period of $30-65$ min, consistent with the time needed to establish a new steadystate level of internal $\mathrm{Cl}^{-}$(Fig. 6B). Recovery of interictal-like activity after bumetanide washout occurred progressively over $40-80 \mathrm{~min}$ and was partial as judged by the amplitude of extracellular field potentials. To demonstrate that bumetanide acted via GABAergic signaling rather than by changing cell volume (Hochman et al., 1995) we induced interictal activity ( $n=5$ of 5 slices) by increasing $\mathrm{K}^{+}$to $12 \mathrm{~mm}$ in the presence of picrotoxin $(100 \mu \mathrm{M})$. This activity was thus independent of $\mathrm{GABA}_{\mathrm{A}}$ receptors and, as shown in Figure 6C, was not suppressed by application of bumetanide ( $10 \mu \mathrm{M} ; n=5$ of 5 slices) for durations exceeding $60 \mathrm{~min}$.

\section{Discussion}

Temporal lobe tissue obtained after surgery provides an opportunity to study pathological changes in neurons and networks of human epileptic patients. We have previously shown that depolarizing GABAergic signaling contributes to epileptiform activity in this tissue (Cohen et al., 2002). Here we report that $\mathrm{GABA}_{\mathrm{A}}$ 


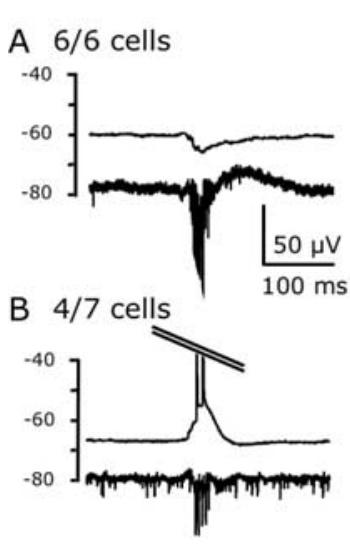

C $3 / 7$ cells

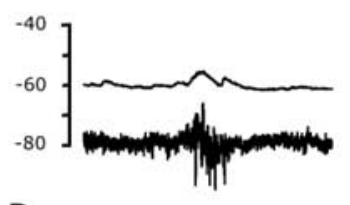

D

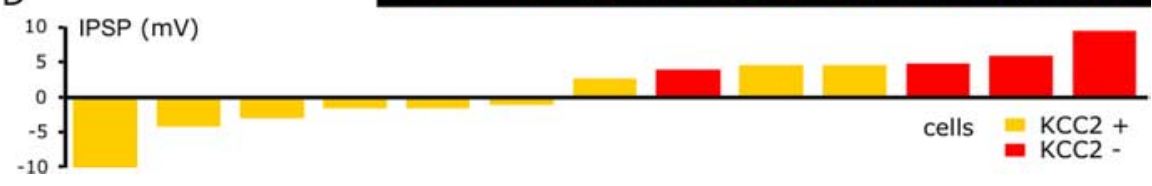

Figure 5. Correlation of pyramidal cell behavior during epileptiform events with KCC2 immunostaining. $\boldsymbol{A}-\boldsymbol{C}$, Left panels are intracellular (top) and extracellular (bottom) records. Right panels are images of a recorded cell filled with biocytin (red) and immunostained for KCC2 (green). Biocytin-filled, KCC2-positive cells are yellow in the merge. Red arrowheads indicate the soma, and open arrowheads indicate the apical dendrite. Confocal fluorescent images of 5-10 $\mu \mathrm{m}$ stack thickness are shown. $\boldsymbol{A}$, Six of six hyperpolarized cells were immmunopositive for KCC2. $\boldsymbol{B}$, Four of seven cells depolarized during interictal bursts were negative for KCC2. C, Three of seven cells depolarized during interictal bursts were positive for KCC2. Some cytoplasmic signal may be nonspecific lipofuscin staining (Yin, 1996). D. Correlation of IPSP reversal potential with the presence (yellow) or absence (red) of KCC2 $(n=13)$. Depolarizing GABAergic events are positive, and hyperpolarizing events are negative.

reversal potentials in subicular pyramidal cells followed a continuous distribution, from hyperpolarized to depolarized values with respect to rest. The $\mathrm{Cl}^{-}$-extruding $\mathrm{K}-\mathrm{Cl}$ transporter $\mathrm{KCC} 2$ was not detected by immunostaining in some, but not all, subicular cells with a perturbed $\mathrm{Cl}^{-}$homeostasis. The diuretic bumetanide, which blocks the $\mathrm{Na}-\mathrm{K}-2 \mathrm{Cl}$ cotransporter, restored hyperpolarizing GABAergic responses and suppressed interictal-like activity.

We showed that GABAergic synaptic events reversed at depolarized potentials from rest in $\sim 20 \%$ of subicular pyramidal cells, a value similar to that reported previously (Cohen et al., 2002). The reversal potential distribution followed a continuum with no clear division into two cell groups (Fig. 2 B). There were no obvious differences in the anatomy or physiology of cells from the extremes of the distribution. The observed IPSP reversal potentials of -75 to $-45 \mathrm{mV}$ are consistent with a variable reduction in KCC2 function in subicular pyramidal cells (Rivera et al., 1999; Ueno et al., 2002; Gulacsi et al., 2003). A similar shift in GABA reversal potential, associated with a loss of KCC2 function, has been observed in pathological conditions including trauma, deafferentation, and paroxysmal activity (Vale and Sanes, 2000; Nabekura et al., 2002; Rivera et al., 2002, 2004; Coull et al., 2003; de Guzman et al., 2006). We identified a group of neurons with depolarized reversal potentials for $\mathrm{GABA}_{\mathrm{A}}$-mediated synaptic responses at the extreme of a continuous distribution. We therefore compared these neurons that discharge with epileptiform field potentials with neurons with more hyperpolarized reversal po- continuously over a range.

tentials. In the absence of true control tissue, we feel this is a meaningful comparison. Normal human subiculum cannot be obtained, and although tumor surgery can provide nonepileptic tissue, the subiculum is rarely removed unless it is infiltrated by the tumor.

We asked whether changes in the expression of the cotransporter KCC2 could account for the perturbation of $\mathrm{Cl}^{-}$homeostasis. Immunohistochemical and in situ data showed nearly all dentate granule cells expressed both mRNA and KCC2 protein. In contrast, no KCC2 mRNA was detected in $\sim 30 \%$ of subicular pyramidal cells (Fig. 3). Immunohistochemistry showed that although a majority of subicular cells expressed KCC2 at both somatic and dendritic membrane sites, it could not be detected in $\sim 10 \%$ of pyramidal cells. This difference recalls the larger reduction in mRNA than in protein observed for KCC2 in the subiculum of pilocarpinetreated rats (de Guzman et al., 2006).

We should note that although immunochemistry and in situ hybridization can demonstrate the presence of a protein or mRNA, it is difficult to derive firm quantitative data. Because several amplification processes are involved, labeling may vary between different samples. In contrast, reversal potentials of GABAergic events (Fig. $2 B$ ) yielded a continuum of values. Thus, whereas in situ hybridization and immunodetection results provided a binary form of data, reversal potential data varied

Despite the difficulty in comparing these two types of data, we found a clear correlation between the activity of biocytin-filled cells during rhythmic interictal activity and immunohistochemical evidence for KCC2 expression. All cells inhibited during population bursts expressed KCC2. Four of seven identified cells that discharged with interictal population bursts did not express KCC2; the other three cells did. This result might be interpreted in several ways. First, immunostaining may recognize low levels of $\mathrm{KCC} 2$ that are not sufficient to assure basal $\mathrm{Cl}^{-}$homeostasis in pyramidal cells. Second, immunodetected KCC2 may not be functional because of its phosphorylation state or other posttranslational mechanisms (Kelsch et al., 2001; Balakrishnan et al., 2003; Vale et al., 2003; Kahle et al., 2005; Khirug et al., 2005; Blaesse et al., 2006). For instance, the depolarizing shift in GABA reversal potential induced by deafferentation of the colliculus has been attributed to posttranslational modifications rather than reduced KCC2 expression (Vale et al., 2003). Third, other molecules that participate in $\mathrm{Cl}^{-}$homeostasis (Staley et al., 1996; Payne et al., 2003; Farrant and Kaila, 2007) may contribute to the shift in GABAergic signaling associated with interictal rhythmicity in human epilepsy.

A recent immunolabeling study in human epileptic tissue has suggested that the $\mathrm{Cl}^{-}$-accumulating cotransporter NKCC1 is upregulated and KCC2 downregulated in some subicular cells of epileptic patients (Munoz et al., 2007). Reverse transcriptionPCR studies support this view, showing an upregulation of 
A

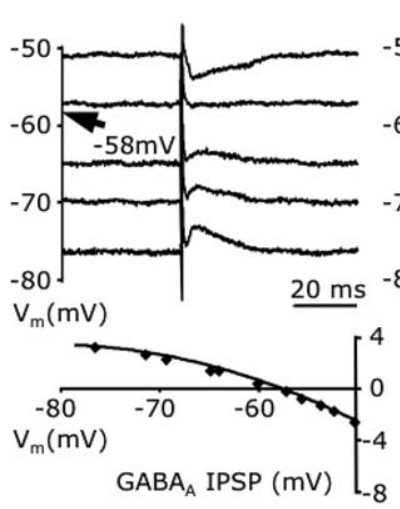

B

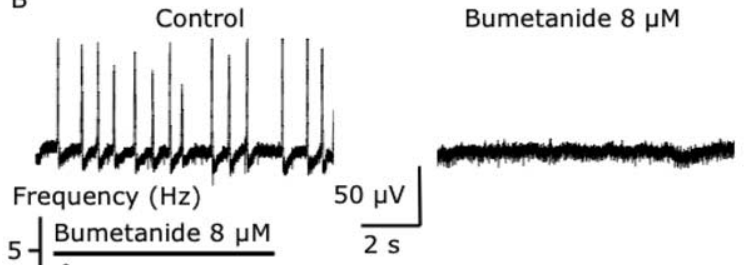

$4-\frac{1}{0}:$

$3-\because \because \because$

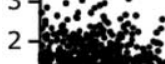

1

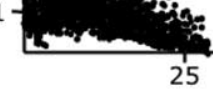

25

C

PTX $100 \mu \mathrm{M}+\mathrm{K}+12 \mathrm{mM}$

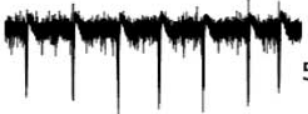

$50 \mu \mathrm{V}$

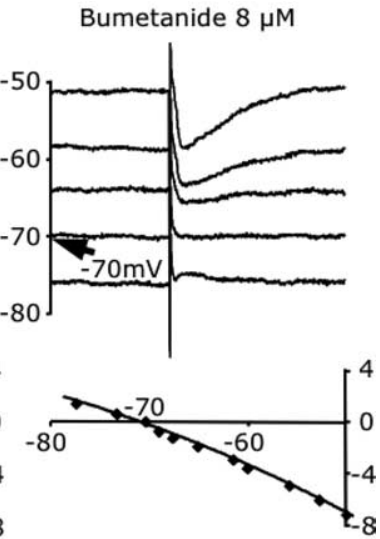

Bumetanide $8 \mu \mathrm{M}$

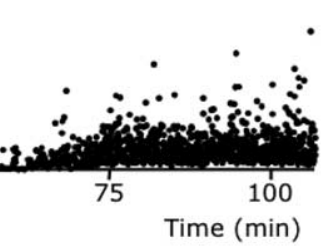

PTX $100 \mu \mathrm{M}+\mathrm{K}+12 \mathrm{mM}$ Bumetanide $8 \mu \mathrm{M}$

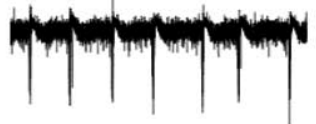

Figure 6. Effects of bumetanide on GABAergic signaling and interictal activity. $\boldsymbol{A}$, Bumetanide $(8 \mu \mathrm{m})$ hyperpolarized the reversal potential of GABAergic IPSPs. Top traces show synaptic events at different membrane potentials $\left(V_{m}\right)$. Reversal potentials are indicated with an arrow. Bottom traces plot IPSP amplitude against membrane potential. $\boldsymbol{B}$, Bumetanide blocked spontaneous epileptiform bursts. Top traces show that extracellular interictal-like field potentials (left) are blocked by bumetanide (right). The bottom plot shows reversible changes in the instantaneous frequency of interictal-like discharges induced by bumetanide application and washout. C, Bumetanide does not affect epileptiform bursts induced by increasing extracellular $\mathrm{K}^{+}$to $12 \mathrm{~mm}$ in the presence of $100 \mu \mathrm{m}$ picrotoxin (PTX).

NKCC1 mRNA and a downregulation of KCC2 mRNA in the human epileptic subiculum compared with hippocampus and lateral neocortex (Palma et al., 2006). Our results with the antagonist bumetanide (Fig. 6) also suggest that NKCC1 is expressed in adult epileptic subiculum. A partial loss of KCC2 function together with an increased NKCC1 expression could affect cellular energy metabolism. Ultimately, both cotransporters depend on gradients established by the Na-K ATPase, using, respectively, $\mathrm{K}^{+}$and $\mathrm{Na}^{+}$gradients to extrude or import $\mathrm{Cl}^{-}$ions (Payne et al., 2003). An impaired KCC2 function could tend to decrease the metabolic costs of maintaining cation gradients. Nevertheless, we identified no other anatomical and electrical properties that could distinguish between cells with a perturbed $\mathrm{Cl}^{-}$homeostasis and the majority of subicular pyramidal cells with hyperpolarizing responses during interictal-like events.

Novel therapeutic options are needed for epilepsies of the medial temporal lobe because existing pharmacotherapies are not optimal. Specifically, drugs that reinforce GABA release or enhance GABA conductances are often ineffective. Our data (Fig. 2) showing that GABA excites some pyramidal cells and inhibits other cells may help explain this poor efficacy. The observation that bumetanide suppressed spontaneous interictal activity (Fig. $6 \mathrm{~B}$ ) adds to evidence that some diuretics may be effective antiepileptic drugs (Dzhala et al., 2005). The effect was mediated via GABAergic signaling rather than possible effects on cell volume (Haglund and Hochman, 2005). Bumetanide can therefore restore dysfunctional $\mathrm{Cl}^{-}$homeostasis at postsynaptic sites in adult epileptic tissue. It would be interesting to test its effects on seizure frequency in patients with temporal lobe epilepsies.

\section{References}

Amaral D, Insausti R (1990) The hippocampal formation. In: The human nervous system (Paxinos G, ed), pp 711-755. San Diego: Academic.

Balakrishnan V, Becker M, Lohrke S, Nothwang HG, Guresir E, Friauf E (2003) Expression and function of chloride transporters during development of inhibitory neurotransmission in the auditory brainstem. J Neurosci 23:4134-4145.

Ben-Ari Y, Cherubini E, Corradetti R, Gaiarsa JL (1989) Giant synaptic potentials in immature rat CA3 hippocampal neurones. J Physiol (Lond) 416:303-325.

Blaesse P, Guillemin I, Schindler J, Schweizer M, Delpire E, Khiroug L, Friauf E, Nothwang HG (2006) Oligomerization of KCC2 correlates with development of inhibitory neurotransmission. J Neurosci 26:10407-10419.

Cohen I, Miles R (2000) Contributions of intrinsic and synaptic activities to the generation of neuronal discharges in in vitro hippocampus. J Physiol (Lond) 524:485-502.

Cohen I, Navarro V, Clemenceau S, Baulac M, Miles R (2002) On the origin of interictal activity in human temporal lobe epilepsy in vitro. Science 298:1418-1421.

Coull JA, Boudreau D, Bachand K, Prescott SA, Nault F, Sik A, De Koninck P, De Koninck Y (2003) Trans-synaptic shift in anion gradient in spinal lamina I neurons as a mechanism of neuropathic pain. Nature 424:938-942.

de Guzman P, Inaba Y, Biagini G, Baldelli E, Mollinari C, Merlo D, Avoli M (2006) Subiculum network excitability is increased in a rodent model of temporal lobe epilepsy. Hippocampus 16:843-860.

de Los Heros P, Kahle KT, Rinehart J, Bobadilla NA, Vazquez N, San Cristobal P, Mount DB, Lifton RP, Hebert SC, Gamba G (2006) WNK3 bypasses the tonicity requirement for $\mathrm{K}-\mathrm{Cl}$ cotransporter activation via a phosphatase-dependent pathway. Proc Natl Acad Sci USA 103:1976-1981.

Dzhala VI, Talos DM, Sdrulla DA, Brumback AC, Mathews GC, Benke TA, Delpire E, Jensen FE, Staley KJ (2005) NKCC1 transporter facilitates seizures in the developing brain. Nat Med 11:1205-1213.

Farrant M, Kaila K (2007) The cellular, molecular and ionic basis of GABA(A) receptor signalling. Brain Res Cogn Brain Res 160:59-87.

Gulacsi A, Lee CR, Sik A, Viitanen T, Kaila K, Tepper JM, Freund TF (2003) Cell type-specific differences in chloride-regulatory mechanisms and $\mathrm{GABA}_{\mathrm{A}}$ receptor-mediated inhibition in rat substantia nigra. J Neurosci 23:8237-8246.

Gulyas AI, Sik A, Payne JA, Kaila K, Freund TF (2001) The KCl cotransporter, KCC2, is highly expressed in the vicinity of excitatory synapses in the rat hippocampus. Eur J Neurosci 13:2205-2217.

Haglund MM, Hochman DW (2005) Furosemide and mannitol suppression of epileptic activity in the human brain. J Neurophysiol 94:907-918

Haug K, Warnstedt M, Alekov AK, Sander T, Ramirez A, Poser B, Maljevic S, Hebeisen S, Kubisch C, Rebstock J, Horvath S, Hallmann K, Dullinger JS, Rau B, Haverkamp F, Beyenburg S, Schulz H, Janz D, Giese B, MullerNewen G, et al. (2003) Mutations in CLCN2 encoding a voltage-gated chloride channel are associated with idiopathic generalized epilepsies. Nat Genet 33:527-532.

Hochman DW, Baraban SC, Owens JW, Schwartzkroin PA (1995) Dissociation of synchronization and excitability in furosemide blockade of epileptiform activity. Science 270:99-102.

Kahle KT, Rinehart J, de Los Heros P, Louvi A, Meade P, Vazquez N, Hebert SC, Gamba G, Gimenez I, Lifton RP (2005) WNK3 modulates transport of $\mathrm{Cl}-$ in and out of cells: implications for control of cell volume and neuronal excitability. Proc Natl Acad Sci USA 102:16783-16788. 
Katchman AN, Vicini S, Hershkowitz N (1994) Mechanism of early anoxiainduced suppression of the GABAA-mediated inhibitory postsynaptic current. J Neurophysiol 71:1128-1138.

Kelsch W, Hormuzdi S, Straube E, Lewen A, Monyer H, Misgeld U (2001) Insulin-like growth factor 1 and a cytosolic tyrosine kinase activate chloride outward transport during maturation of hippocampal neurons. J Neurosci 21:8339-8347.

Khalilov I, Holmes GL, Ben-Ari Y (2003) In vitro formation of a secondary epileptogenic mirror focus by interhippocampal propagation of seizures. Nat Neurosci 6:1079-1085.

Khirug S, Huttu K, Ludwig A, Smirnov S, Voipio J, Rivera C, Kaila K, Khiroug L (2005) Distinct properties of functional KCC2 expression in immature mouse hippocampal neurons in culture and in acute slices. Eur J Neurosci 21:899-904.

Menendez de la Prida L, Suarez F, Pozo MA (2003) Electrophysiological and morphological diversity of neurons from the rat subicular complex in vitro. Hippocampus 13:728-744.

Miller MA, Kolb PE, Raskind MA (1993) A method for simultaneous detection of multiple mRNAs using digoxigenin and radioisotopic cRNA probes. J Histochem Cytochem 41:1741-1750.

Munoz A, Mendez P, DeFelipe J, Alvarez-Leefmans FJ (2007) Cationchloride cotransporters and GABA-ergic innervation in the human epileptic hippocampus. Epilepsia 48:663-673.

Nabekura J, Ueno T, Okabe A, Furuta A, Iwaki T, Shimizu-Okabe C, Fukuda A, Akaike N (2002) Reduction of KCC2 expression and $\mathrm{GABA}_{\mathrm{A}}$ receptor-mediated excitation after in vivo axonal injury. J Neurosci 22:4412-4417.

Palma E, Amici M, Sobrero F, Spinelli G, Di Angelantonio S, Ragozzino D, Mascia A, Scoppetta C, Esposito V, Miledi R, Eusebi F (2006) Anomalous levels of $\mathrm{Cl}$ - transporters in the hippocampal subiculum from temporal lobe epilepsy patients make GABA excitatory. Proc Natl Acad Sci USA 103:8465-8468.

Payne JA (1997) Functional characterization of the neuronal-specific K-Cl cotransporter: implications for $[\mathrm{K}+]_{\mathrm{o}}$ regulation. Am J Physiol 273:C1516-C1525.

Payne JA, Stevenson TJ, Donaldson LF (1996) Molecular characterization of a putative $\mathrm{K}-\mathrm{Cl}$ cotransporter in rat brain. A neuronal-specific isoform. J Biol Chem 271:16245-16252.

Payne JA, Rivera C, Voipio J, Kaila K (2003) Cation-chloride cotransporters in neuronal communication, development and trauma. Trends Neurosci 26:199-206.

Plotkin MD, Snyder EY, Hebert SC, Delpire E (1997) Expression of the $\mathrm{Na}-\mathrm{K}-2 \mathrm{Cl}$ cotransporter is developmentally regulated in postnatal rat brains: a possible mechanism underlying GABA's excitatory role in immature brain. J Neurobiol 33:781-795.

Rivera C, Voipio J, Payne JA, Ruusuvuori E, Lahtinen H, Lamsa K, Pirvola U, Saarma M, Kaila K (1999) The $\mathrm{K}+/ \mathrm{Cl}-$ co-transporter KCC2 renders GABA hyperpolarizing during neuronal maturation. Nature 397:251-255.

Rivera C, Li H, Thomas-Crusells J, Lahtinen H, Viitanen T, Nanobashvili A,
Kokaia Z, Airaksinen MS, Voipio J, Kaila K, Saarma M (2002) BDNFinduced $\operatorname{TrkB}$ activation down-regulates the $\mathrm{K}+-\mathrm{Cl}-$ cotransporter KCC2 and impairs neuronal Cl- extrusion. J Cell Biol 159:747-752.

Rivera C, Voipio J, Thomas-Crusells J, Li H, Emri Z, Sipila S, Payne JA, Minichiello L, Saarma M, Kaila K (2004) Mechanism of activitydependent downregulation of the neuron-specific $\mathrm{K}-\mathrm{Cl}$ cotransporter KCC2. J Neurosci 24:4683-4691.

Russell JM (2000) Sodium-potassium-chloride cotransport. Physiol Rev $80: 211-276$.

Semah F, Picot MC, Adam C, Broglin D, Arzimanoglou A, Bazin B, Cavalcanti $\mathrm{D}$, Baulac M (1998) Is the underlying cause of epilepsy a major prognostic factor for recurrence? Neurology 51:1256-1262.

Sik A, Hajos N, Gulacsi A, Mody I, Freund TF (1998) The absence of a major $\mathrm{Ca} 2+$ signaling pathway in GABAergic neurons of the hippocampus. Proc Natl Acad Sci USA 95:3245-3250.

Sipila ST, Schuchmann S, Voipio J, Yamada J, Kaila K (2006) The cationchloride cotransporter NKCC1 promotes sharp waves in the neonatal rat hippocampus. J Physiol (Lond) 573:765-773.

Staley K, Smith R, Schaack J, Wilcox C, Jentsch TJ (1996) Alteration of GABAA receptor function following gene transfer of the CLC-2 chloride channel. Neuron 17:543-551.

Stewart M, Wong RK (1993) Intrinsic properties and evoked responses of guinea pig subicular neurons in vitro. J Neurophysiol 70:232-245.

Topolnik L, Steriade M, Timofeev I (2003) Hyperexcitability of intact neurons underlies acute development of trauma-related electrographic seizures in cats in vivo. Eur J Neurosci 18:486-496.

Ueno T, Okabe A, Akaike N, Fukuda A, Nabekura J (2002) Diversity of neuron-specific $\mathrm{K}+-\mathrm{Cl}-$ cotransporter expression and inhibitory postsynaptic potential depression in rat motoneurons. J Biol Chem 277:4945-4950.

Vale C, Sanes DH (2000) Afferent regulation of inhibitory synaptic transmission in the developing auditory midbrain. J Neurosci 20:1912-1921.

Vale C, Schoorlemmer J, Sanes DH (2003) Deafness disrupts chloride transporter function and inhibitory synaptic transmission. J Neurosci 23:7516-7524.

van den Pol AN, Obrietan K, Chen G (1996) Excitatory actions of GABA after neuronal trauma. J Neurosci 16:4283-4292.

Vanhatalo S, Palva JM, Andersson S, Rivera C, Voipio J, Kaila K (2005) Slow endogenous activity transients and developmental expression of $\mathrm{K}+-\mathrm{Cl}-$ cotransporter 2 in the immature human cortex. Eur J Neurosci 22:2799-2804.

West MJ, Slomianka L, Gundersen HJ (1991) Unbiased stereological estimation of the total number of neurons in the subdivisions of the rat hippocampus using the optical fractionator. Anat Rec 231:482-497.

Williams JR, Payne JA (2004) Cation transport by the neuronal $\mathrm{K}(+)$ $\mathrm{Cl}(-)$ cotransporter KCC2: thermodynamics and kinetics of alternate transport modes. Am J Physiol Cell Physiol 287:C919-C931.

Yin D (1996) Biochemical basis of lipofuscin, ceroid, and age pigment-like fluorophores. Free Radic Biol Med 21:871-888. 